\title{
Thrombin inhibits osteoclast differentiation through a non-proteolytic mechanism
}

\author{
S Sivagurunathan*, C N Pagel*, L H Loh, L C Wijeyewickrema', R N Pike ${ }^{1}$ and E J Mackie \\ Faculty of Veterinary Science, University of Melbourne, Parkville, Victoria 3010, Australia \\ ${ }^{1}$ Department of Biochemistry and Molecular Biology, Monash University, Clayton, Victoria 3800, Australia \\ *(S Sivagurunathan and C N Pagel contributed equally to this work)
}

Correspondence should be addressed to E J Mackie

Email

ejmackie@unimelb.edu.au

\begin{abstract}
Thrombin stimulates expression of interleukin 6 and cyclooxygenase 2 by osteoblasts, both of which enhance osteoblast-mediated osteoclast differentiation by increasing the ratio of receptor activator of nuclear factor $\kappa B$ ligand (RANKL) expression to that of osteoprotegerin (OPG) in osteoblasts. We hypothesised that thrombin would also increase this ratio and thereby stimulate osteoclast differentiation in mixed cultures of osteoblastic cells and osteoclast precursors. In primary mouse osteoblasts, but not in bone marrow stromal cells, thrombin increased the ratio of RANKL to OPG expression. Thrombin inhibited differentiation of osteoclasts, defined as tartrate-resistant acid phosphatase (TRAP)-positive cells with three or more nuclei, in mouse bone marrow cultures treated with osteoclastogenic hormones; this effect was not mediated by the major thrombin receptor, protease-activated receptor 1, nor did it require thrombin's proteolytic activity. Thrombin also caused a decrease in the number of TRAP-positive cells with fewer than three nuclei. Thrombin (active or inactive) also inhibited osteoclast differentiation and bone resorption, respectively, in cultures of mouse spleen cells and human peripheral blood mononuclear cells induced to undergo osteoclastogenesis by treatment with RANKL and macrophage colony-stimulating factor. Osteoclast differentiation in spleen cells was inhibited when they were exposed to thrombin from days 0 to 3 or 3 to 5 of culture but not days 5 to 7 when most fusion occurred. Thrombin inhibited expression of RANK by spleen cells. These observations indicate that, although thrombin stimulates production of osteoclastogenic factors by osteoblastic cells, it inhibits the early stages of RANKL-induced osteoclast differentiation through a direct effect on osteoclast precursors that does not require thrombin's proteolytic activity.
\end{abstract}

\author{
Key Words \\ - thrombin \\ - osteoclast \\ - protease-activated receptor 1 \\ - RANKL \\ - osteoprotegerin
}

Journal of Molecular Endocrinology (2013) 50, 347-359

\section{Introduction}

Osteoclasts, the multinucleate cells responsible for bone resorption, are derived from the monocyte-macrophage lineage of haemopoietic cells. The other major bone cell lineage is that of the bone-forming osteoblasts. Osteoblasts and their precursors express two factors that are essential for osteoclast differentiation and activity: macrophage colony-stimulating factor (M-CSF) and receptor activator of nuclear factor $\kappa \mathrm{B}$ ligand (RANKL) (Ross 2008). Many factors that stimulate osteoclast differentiation, including parathyroid hormone (PTH), prostaglandin $\mathrm{E}_{2}\left(\mathrm{PGE}_{2}\right), 1,25$-dihydroxyvitamin $\mathrm{D}_{3}(1,25 \mathrm{D})$ and interleukin 6 (IL6), do so by stimulating an increase in

Published by Bioscientifica Ltd. 
the expression of RANKL relative to that of its soluble decoy receptor osteoprotegerin (OPG) (Okada et al. 2000, Braun \& Zwerina 2011).

The blood coagulation protease, thrombin, exerts hormone-like effects on cells including osteoblasts. For example, thrombin stimulates proliferation and inhibits apoptosis of cultured osteoblasts (Tatakis et al. 1989, Abraham \& Mackie 1999, Pagel et al. 2003). Thrombin also stimulates expression of IL6 and cyclooxygenase 2 (COX2) mRNA, as well as IL6 and $\mathrm{PGE}_{2}$ secretion by osteoblasts (Feyen et al. 1984, Kozawa et al. 1997, Pagel et al. 2009). Thrombin's stimulation of osteoblastic proliferation and IL6 and $\mathrm{PGE}_{2}$ release are mediated by protease-activated receptor $1\left(\mathrm{PAR}_{1}\right)$, a member of the PAR group of seven-transmembrane domain $G$ proteincoupled receptors (Abraham \& Mackie 1999, Song et al. 2005b, Pagel et al. 2009). PARs are activated by proteolytic cleavage of their extracellular domain, creating a new N-terminus that binds to the second extracellular loop of the same receptor molecule, thus activating intracellular signalling pathways (Mackie et al. 2008). Thrombin's inhibition of osteoblast apoptosis, by contrast, is not mediated by any of the PARs although it is dependent on an interaction between proteolytically active thrombin and the cells (Pagel et al. 2003).

In the bone environment, active thrombin is generated upon initiation of blood coagulation as a result of bone fracture, as well as in rheumatoid arthritis and possibly other inflammatory conditions affecting bone such as periodontal disease (Mackie et al. 2008). It is thus important to understand the full range of responses of bone cells elicited by this potent biological agent. The current study was initiated to investigate the hypothesis that thrombin-induced secretion of IL6 and PGE 2 leads to an increase in the ratio of RANKL:OPG in osteoblastic cells and thus increased osteoclast differentiation in mixed populations of cells of the osteoblast and osteoclast lineages. When it was determined that, contrary to expectations, thrombin inhibits osteoclast differentiation induced by a variety of osteoclastogenic factors, further studies were undertaken to investigate the mechanism of the effect.

\section{Materials and methods}

\section{Materials}

Tissue culture media and heparin sodium salt were purchased from Gibco-Invitrogen (Life Technologies). FCS was purchased from JRH Bioscience (Lenexa, KS, USA). Recombinant human and mouse RANKL were from
PeproTech Asia (Rehovot, Israel). Recombinant human and mouse M-CSF were from R\&D Systems (Minneapolis, $\mathrm{MN}, \mathrm{USA}) . \mathrm{PGE}_{2}$ was obtained from Cayman Chemicals (Ann Arbour, MI, USA). All reagents for PCR were obtained from Promega. Primers and oligonucleotides were custom synthesised by Geneworks (Adelaide, SA, Australia). The thrombin inhibitor D-phenylalanyl-L-prolyl-L-argininechloromethyl ketone (PPACK) was obtained from Calbiochem (San Diego, CA, USA). Rabbit thrombomodulin was obtained from Haematologic Technologies, Inc. (Essex Junction, VT, USA). Hirudin fragment 54-65 and all other chemicals and reagents were purchased from Sigma-Aldrich unless otherwise stated.

Thrombin from three different sources was used in the study. Human plasma $\alpha$-thrombin was purified as described by Stone \& Hofsteenge (1986). Any contaminating lipopolysaccharide was removed using a Detoxi-Gel column (Pierce Biotechnology, Rockford, IL, USA) according to the manufacturer's instructions. The active concentration of thrombin was determined as described by Pagel et al. (2009). Human $\alpha$-thrombin was also purchased from Haematologic Technologies, Inc., and recombinant human $\alpha$-thrombin was expressed and purified as described by Johnson et al. (2005). The data presented in the paper were obtained with thrombin purified by the authors, unless otherwise indicated. Thrombin was used at a concentration of $100 \mathrm{nmol} / \mathrm{l}$ unless otherwise specified. Catalytically inactive thrombin was prepared by incubating thrombin (100 nmol/l) with PPACK $(1 \mu \mathrm{mol} / \mathrm{l})$ for $15 \mathrm{~min}$ at $37^{\circ} \mathrm{C}$; inactivation was confirmed by thrombin activity assays using the chromogenic substrate S-2238, as described by Pagel et al. (2003). The purity of thrombin preparations was confirmed by comparing their appearance on silver-stained gels with that on western blots, prepared as described below; for all sources of thrombin, all bands visible on the silverstained gels were visible on western blots (Fig. 1).

\section{Mice}

$\mathrm{PAR}_{1}$-null (Connolly et al. 1996) mice on the C57BL/6J background were kindly provided by Dr S R Coughlin (University of California, San Francisco, USA). The breeding colony is maintained through heterozygous mating at the Faculty of Veterinary Science, University of Melbourne; mice used for primary cell culture were either littermates or the offspring of littermates. All work involving primary culture of mouse cells was approved by the Animal Ethics Committee of the University of Melbourne.

Published by Bioscientifica Ltd. 


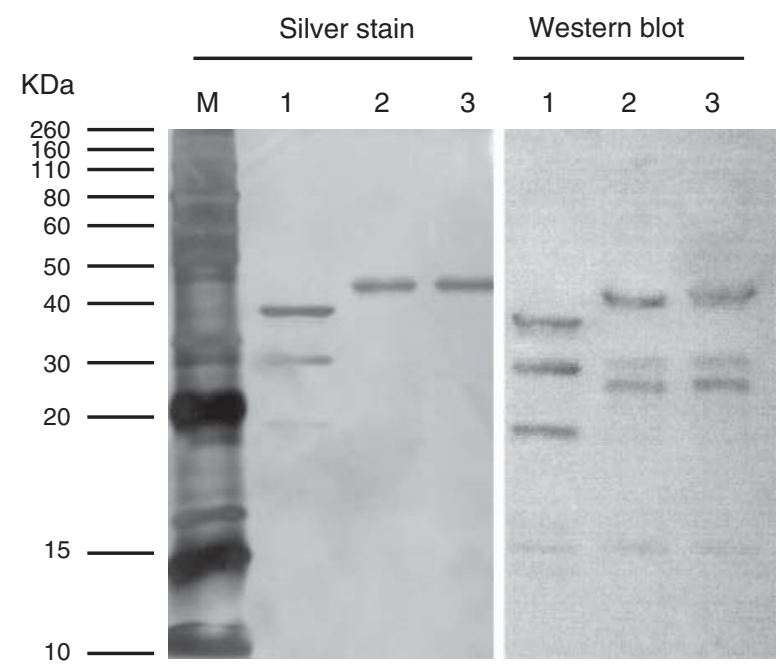

Figure 1

Gel electrophoresis of thrombin preparations. Thrombin preparations were subjected to SDS-PAGE followed by silver staining (left) or transferred to nitrocellulose and probing with anti-thrombin antibody and detection by chemiluminescence (right). Lane 1, recombinant human thrombin; Lane 2, human plasma thrombin purified by the authors and Lane 3, commercial human plasma thrombin. $\mathrm{M}$, molecular weight markers.

\section{Cell culture}

Primary calvarial osteoblasts were collected by sequential collagenase digestion of calvariae from $\mathrm{PAR}_{1}$-null and wild-type mice as described by Pagel et al. (2003). Cells were maintained in DMEM with $10 \%(\mathrm{v} / \mathrm{v})$ heat-inactivated FCS, L-glutamine $(300 \mu \mathrm{g} / \mathrm{ml})$, gentamicin $(50 \mu \mathrm{g} / \mathrm{ml})$ and amphotericin B $(2.5 \mu \mathrm{g} / \mathrm{ml})$. The medium was changed every second day and cultures were maintained in a humidified atmosphere at $37^{\circ} \mathrm{C}$ under $5 \% \mathrm{CO}_{2}$ in air. At first passage, osteoblasts were plated in six-well plates for RNA extraction. Following attachment, cells to be used for RNA extraction were treated with serum-free medium in the absence or presence of thrombin.

Bone marrow cells were prepared from tibiae and femurs of 6-9-week-old $\mathrm{PAR}_{1}$-null and wild-type mice as described by Smith et al. (2004). The marrow cavity was flushed with an $\alpha$-minimum essential medium ( $\alpha$-MEM) with penicillin $(0.03 \mathrm{~g} / \mathrm{l})$, streptomycin $(0.01 \mathrm{~g} / \mathrm{l})$ and $10 \%(\mathrm{v} / \mathrm{v})$ heat-inactivated FCS ( $\alpha$-MEM/FCS). In some experiments, bone marrow stromal cells were allowed to adhere to plastic-culture-ware surfaces for $48 \mathrm{~h}$ before harvesting by trypsinisation.

For the culture of whole bone marrow, cells were washed and cultured in $\alpha$-MEM/FCS in 24-well plates containing glass coverslips at $2 \times 10^{6}$ cells $/ \mathrm{ml}$ in a volume of $500 \mu \mathrm{l}$. Treatments consisting of various combinations (as indicated in the Results section) of human PTH 1-34 (10 nmol/l), 1,25D (10 nmol/l), PGE $_{2}(1 \mu \mathrm{mol} / \mathrm{l})$, thrombin (100 nmol/l), PPACK $(1 \mu \mathrm{mol} / \mathrm{l})$ and PPACK-inactivated thrombin (100 nmol/l unless otherwise specified) were added after a $24 \mathrm{~h}$ attachment period and at each medium change. Cultures were maintained by removing $450 \mu \mathrm{l}$ medium and replacing with $500 \mu \mathrm{l}$ fresh medium every 3 days. Cultures were maintained for 7-10 days.

Bone marrow stromal cells were plated in six-well plates at $10^{6}$ cells/well and cultured in a serum-free $\alpha$-MEM for $24 \mathrm{~h}$ before treatment with thrombin $(100 \mathrm{nmol} / \mathrm{l})$ for $24 \mathrm{~h}$. Media, conditioned by control and thrombintreated bone marrow stromal cells, were collected and cells were either lysed for ELISA in phosphate buffer containing 1\% Triton X or were lysed for RNA preparation as described below.

Spleen cells were isolated from 6- to 9-week-old $\mathrm{PAR}_{1}$-null and wild-type mice (Li et al. 2000, Okada et al. 2000) using a cell strainer (70 $\mu \mathrm{m}$; BD Bioscience, San Jose, CA, USA). The cell suspension was pelleted and resuspended in $\alpha$-MEM/FCS. T cells were removed from mouse spleen cells using mouse pan $\mathrm{T}$ (Thy 1.2) Dynabeads (Life Technologies; John et al. 1996). In some experiments, the remaining spleen cells were plated at $5 \times 10^{5}$ cells/well in a 48-well plate containing glass coverslips and then cultured with mouse RANKL $(25 \mathrm{ng} / \mathrm{ml})$ and mouse M-CSF (50 ng/ml) together with various combinations of thrombin $(100 \mathrm{nmol} / \mathrm{l})$, PPACK $(1 \mu \mathrm{mol} / \mathrm{l})$, PPACK-inactivated thrombin (100 nmol/l), hirudin fragment 54-65 $(10 \mu \mathrm{mol} / \mathrm{l})$, heparin $(100 \mu \mathrm{g} / \mathrm{ml})$, thrombomodulin $(200 \mathrm{nmol} / \mathrm{l})$ or vehicle in $\alpha$-MEM/FCS for 7 days, unless otherwise indicated; in experiments involving hirudin fragment, heparin and thrombomodulin, polymixin B $(10 \mu \mathrm{mol} / \mathrm{l})$ was included in all treatments to inactivate any lipopolysaccharide that may have been present in these reagents; these cultures were then stained for the presence of osteoclasts (described below). In some experiments, the $\mathrm{T}$ cell-depleted spleen cells were plated in six-well plates $\left(6.4 \times 10^{6}\right.$ cells/well $)$ and treated with RANKL and M-CSF together with vehicle or thrombin for 1, 3 or 5 days, before RNA extraction.

Human osteoclasts were cultured from buffy coats of donor blood (Australian Red Cross, Melbourne, VIC, Australia), diluted 1:1 in PBS, layered over $10 \mathrm{ml}$ FicollHypaque (GE Healthcare Life Sciences, Piscataway, NJ, USA) and centrifuged at $900 \boldsymbol{g}$ for $30 \mathrm{~min}$. A layer of monocytes was extracted from the interface of the PBS and Ficoll-Hypaque and centrifuged at $400 \boldsymbol{g}$ for $5 \mathrm{~min}$. The cell pellet was rinsed and washed in $\alpha$-MEM/FCS. Cells were counted using a haemocytometer to determine the

Published by Bioscientifica Ltd. 
number of mononuclear cells. Peripheral blood mononuclear cells (PBMCs) were seeded in 96-well plates containing dentine slices $(4 \times 4 \times 0.2 \mathrm{~mm})$ at a concentration of $1 \times 10^{6}$ cells/well in $\alpha$-MEM/FCS. After incubation at $37^{\circ} \mathrm{C}$ for $2 \mathrm{~h}$, the cells were rinsed twice with $\alpha$-MEM/FCS to remove any non-attached cells. Cells were cultured for 21 days in $150 \mu \mathrm{l} \alpha$-MEM/FCS containing human RANKL (30 ng/ml), human M-CSF (25 ng/ml) and thrombin or vehicle; thrombin was present in the medium for the full culture period unless otherwise indicated.

\section{Identification of osteoclasts}

Histochemical staining for the osteoclast marker tartrateresistant acid phosphatase (TRAP) was used to assist in the identification of osteoclasts in cultures. At the end of the culture period, cells were fixed with $4 \%(\mathrm{w} / \mathrm{v})$ paraformaldehyde in PBS for $3 \mathrm{~min}$ and 1:1 acetone/ethanol for $30 \mathrm{~s}$ and then stained for acid phosphatase using naphthol AS-TR phosphate (Minkin 1982) and then mounted in aqueous mountant containing 4',6-diamidino-2-phenylindole (DAPI; $1 \mu \mathrm{g} / \mathrm{ml}$ ). Osteoclasts were counted as TRAP-positive multinucleate cells (cells with three or more nuclei; TRAP +MNC); results are expressed as TRAP $+\mathrm{MNC/dentine} \mathrm{slice} \mathrm{or} \mathrm{well.} \mathrm{The} \mathrm{number} \mathrm{of} \mathrm{DAPI-}$ positive nuclei present in cultures was determined from three random fields for each well. Low-power digital images were captured and the number of fluorescent objects per field was counted using Image-Pro Plus version 4.1 (Media Cybernetics, Rockville, MD, USA). Results for each treatment are presented as mean number of nuclei per field from three wells.

Resorption was assayed by assessing the ability of human PBMCs cultured for 21 days to form resorption pits on the surface of dentine slices. At the end of the culture period, cells were removed and processed for scanning electron microscopy as described by Sivagurunathan $e t$ al. (2005). Dentine slices were sputter-coated with gold with an Edwards S 150B sputter coater and examined using a Philips XL Field Emission Scanning Electron Microscope; digital images were collected for each slice. Using ImagePro Plus version 4.1 (Media Cybernetics), a grid was placed over each micrograph. The total number of points on each grid provided a measure of total area, and the number of points overlying resorption pits was counted as a measure of resorption area, which was expressed as a percentage of total area (Howard \& Reed 1998). For each dentine slice, four random areas were chosen to estimate the percentage area resorbed.

\section{Plasmid construction, RNA extraction and quantitative RT-PCR}

Oligonucleotide primers for detection of expression of RANKL, OPG and a number of osteoclast genes were designed using Primer3 Software (http://primer3.source. force.net/) and are presented in Table 1 . The sequences of primers for glyceraldehyde-3-phosphate dehydrogenase (GAPDH) were as described by Pagel et al. (2009).

RNA samples from calvarial osteoblasts were used to amplify RANKL and OPG genes with BIOTAQ DNA polymerase (Bioline, London, UK) according to the manufacturer's instructions, and the products were purified using a Wizard SV Gel and PCR clean-up system (Promega) according to the manufacturer's instructions. The purified products were cloned into pGEM-T easy vector (Promega) and the recombinant plasmids were transformed into XL1 Blue competent cells (Agilent Technologies, Santa Clara, CA, USA) for antibiotic selection and DNA preparation. Purified plasmids were linearised by EcoR1 restriction digestion, and DNA was quantified by absorbance at $260 \mathrm{~nm}$. Serial dilutions of the linearised plasmid were made from $10^{6}$ to $10^{2}$ single-stranded DNA molecules/ $\mu$ for the construction of a standard curve for each experiment involving quantification of RANKL and OPG expressions (Smith et al. 2003, Tsubakihara et al. 2004).

Total RNA was isolated from cell layers by lysis, using the SV Total RNA isolation system (Promega). First-strand synthesis of cDNA was performed using $1 \mu \mathrm{g}$ total RNA primed with Oligo $\mathrm{dT}_{15}$ (Promega) in $25 \mu \mathrm{l}$ reactions

Table 1 Primer sequences

\begin{tabular}{l} 
Gene \\
\hline OPG (Tnfrsf11b) \\
RANKL (Tnfsf11) \\
RANK (Tnfrsf11a) \\
Oscar \\
c-fos (Fos) \\
c-fms (Csf1r)
\end{tabular}

\begin{tabular}{l} 
Forward primer $\left(5^{\prime}-3^{\prime}\right)$ \\
\hline GAA CCC CAG AGC GAA ATA CA \\
CAT TTG CAC ACC TCA CCA TC \\
CTG ATG AGA GGG GAG CCT CA \\
TGT CGA CTC TCT GTG AGC TGT \\
ATG GGC TCT CCT GTC AAC AC \\
CGA GGG AGA CTC CAG CTA CA \\
\hline
\end{tabular}

Reverse primer $\left(5^{\prime}-3^{\prime}\right)$

CCT GAA GAA TGC CTC CTC AC GTG CTC CCT CCT TTC ATC AG TGA AGT TCA TCA CCT GCC CG GAT CCC AGG AGT CAC AAC TGC TGT CAC CGT GGG GAT AAA GT GCT GGT CAA CAG CAC GTT TC http://jme.endocrinology-journals.org DOI: 10.1530/JME-12-0177
๑) 2013 Society for Endocrinology Printed in Great Britain
Published by Bioscientifica Ltd 
including $5 \mu \mathrm{l}$ of $5 \times$ reverse transcriptase buffer, dNTPs $(2 \mathrm{nmol} / \mathrm{l})$ and $100 \mathrm{U}$ MM-LV reverse transcriptase (RNase H; all from Promega); the reaction was carried out according to the manufacturer's instructions. Quantitative RT-PCR (qRT-PCR) reactions were performed in a total volume of $20 \mu \mathrm{l}$, with $10 \mu \mathrm{l}$ Applied Biosystems SYBR Green PCR Master Mix (Life Technologies), forward and reverse primers (each $250 \mathrm{nmol} / \mathrm{l}$ ) and $2 \mu \mathrm{l}$ cDNA template in accordance with the manufacturer's instructions. Reactions were performed on an MX3000p Real-Time PCR Machine (Agilent Technologies) by denaturing at $95{ }^{\circ} \mathrm{C}$ for $15 \mathrm{~min}$, followed by $40-70$ cycles of denaturation at $95^{\circ} \mathrm{C}$ for $30 \mathrm{~s}$, annealing at $60^{\circ} \mathrm{C}$ for $30 \mathrm{~s}$ and extension at $72^{\circ} \mathrm{C}$ for $30 \mathrm{~s}$. RANKL and OPG gene expressions were analysed by absolute quantification; varying concentrations of plasmid DNA $\left(10^{2}, 10^{3}, 10^{4}, 10^{5}\right.$ and $10^{6}$ copies/ $\left.\mu \mathrm{l}\right)$ were used to create a standard curve. The quantity of target gene in the samples was determined from the standard curves using MX3000p Real-Time PCR Machine Software and expressed as copies/ $\mu \mathrm{g}$ RNA. The expression of osteoclast genes was normalised to that of GAPDH and data are presented as mean-normalised expression calculated using the Q-Gene Software (http://www.gene-quantification.de/) application (Muller et al. 2002).

\section{Protein gel electrophoresis}

RANKL (30 ng/ml) and M-CSF (25 ng/ml) in PBS containing $0.1 \%(\mathrm{w} / \mathrm{v}) \mathrm{BSA}$ were incubated with thrombin $(100 \mathrm{nmol} / \mathrm{l})$ for $30 \mathrm{~min}$ at $37^{\circ} \mathrm{C}$ before the thrombin inhibitor PPACK (Calbiochem) was added to a final concentration of $1 \mu \mathrm{mol} / \mathrm{l}$; the mixture was incubated for $15 \mathrm{~min}$ at $37^{\circ} \mathrm{C}$. The protein mixture was then subjected to $12 \%$ SDS-PAGE and transferred onto nitrocellulose membranes (GE Healthcare Life Sciences) or silver staining (Morrissey 1981). Nitrocellulose membranes were incubated with monoclonal anti-human RANKL antibody (R\&D Systems) or sheep anti-bovine thrombin antibody (Affinity Biologicals, Ancaster, ON, Canada), followed by incubation with anti-mouse HRP (Dako A/S, Glostrup, Denmark). The results were visualised using an ECL Chemiluminescence Detection Kit (GE Healthcare
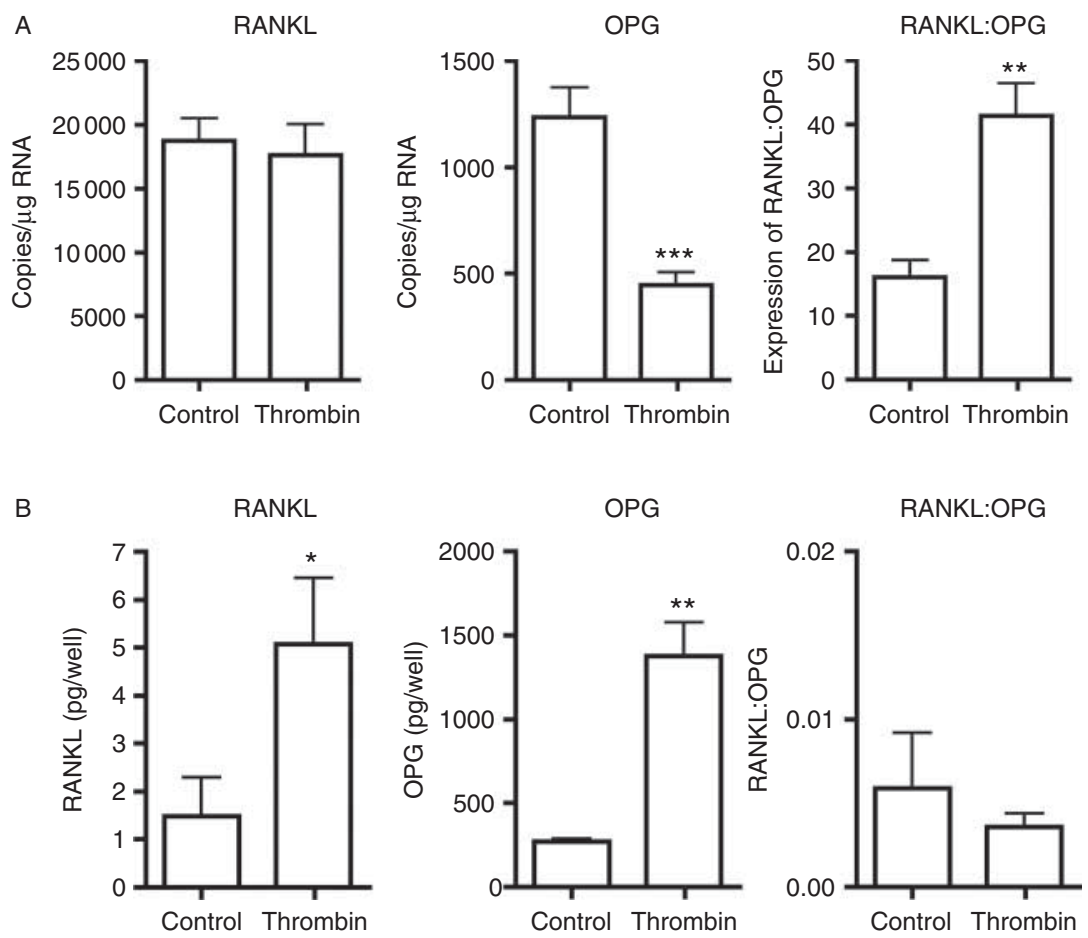

Figure 2

Effects of thrombin on RANKL and OPG expressions. (A) Quantitative PCR analysis of expression of RANKL and OPG mRNA, and the ratio of RANKL:OPG, in primary calvarial osteoblasts cultured for $24 \mathrm{~h}$ in a serum free-medium in the absence or presence of thrombin $(100 \mathrm{nmol} / \mathrm{l})$. Results are presented as copies/ug RNA (mean \pm s.E.M.; $n=3$ ). (B) ELISA analysis of expression of RANKL and OPG, and the ratio of RANKL:OPG, in bone marrow stromal cells cultured for $24 \mathrm{~h}$ in a serum free-medium in the absence or presence of thrombin $(100 \mathrm{nmol} / \mathrm{l})$. Results are the combined values for the medium and cell layer for each well (pg/well; mean \pm s.E.M.; $n=3$ ). Two-tailed Student's $t$-test: ${ }^{*} P<0.05, * * P<0.01$ and $* * * P<0.001$ for comparisons between treatment and control. http://jme.endocrinology-journals.org DOI: 10.1530/JME-12-0177
(๑) 2013 Society for Endocrinology Printed in Great Britain
Published by Bioscientifica Ltd 
Life Sciences). Immunoreactive proteins were visualised using a Chemi-Smart 2000 (Vilber Lourmat, Marnela-Vallée, France).

\section{ELISA}

The levels of RANKL and OPG present in bone marrow stromal cell cultures were measured using RANKL and OPG ELISA kits (R\&D Systems) in accordance with the manufacturer's instructions. The amounts of RANKL and OPG present in cell lysates and conditioned medium from each well were combined to give a total value per well.

\section{Statistical analysis}

Data are presented as the mean \pm s.e.m. Data were analysed by two-tailed Student's $t$-test, one-way ANOVA and Dunnett's post-hoc test or two-way ANOVA or Bonferroni's post-hoc test, as appropriate, except for qRT-PCR results for osteoclast genes, which were analysed for significant differences by a 2000 sample, pairwise fixed reallocation randomisation test, using REST-384 free software (Pfaffl et al. 2002). All data presented here are representative results of at least two similar experiments.

\section{Results}

\section{The effect of thrombin on the expression of RANKL and OPG}

The expression of OPG and RANKL mRNA was quantified by absolute qRT-PCR in primary calvarial osteoblasts treated with or without thrombin for $24 \mathrm{~h}$ in a serum-free medium. Thrombin, used at a concentration (100 nmol/l) that stimulates maximal responses of osteoblasts and bone marrow stromal cells in a variety of assays (Pagel et al. 2003, Song et al. 2005a), had no effect on the expression of RANKL mRNA but significantly suppressed the expression of OPG mRNA and thus significantly increased the ratio of RANKL:OPG (Fig. 2A). By contrast, in bone marrow stromal cells, thrombin stimulated both RANKL and OPG expressions, as detected by ELISA, resulting in no significant change in the ratio of RANKL:OPG (Fig. 2B); this ratio was similarly unchanged in qRT-PCR studies on bone marrow stromal cells (data not shown).

\section{The effect of thrombin on osteoclast differentiation}

The ability of thrombin to modulate osteoclastogenesis was initially investigated in murine bone marrow cultures, because bone marrow contains both osteoclast precursors and the stromal cells of the osteoblast lineage capable of expressing the RANKL and M-CSF that are necessary for osteoclast differentiation. The effect of thrombin on osteoclast differentiation was investigated in cells isolated from wild-type mice and treated with or without PTH or $1,25 \mathrm{D}$ and $\mathrm{PGE}_{2}$ for 10 days. In the absence of these osteoclastogenic factors, no TRAP + MNC were formed, whether or not thrombin was present; in cultures treated with PTH or 1,25D and $\mathrm{PGE}_{2}$, thrombin significantly decreased the number of TRAP + MNC (Fig. 3A). Thrombin exerted a similar effect on bone marrow cells isolated from $\mathrm{PAR}_{1}$-null mice (Fig. 3B). Moreover, catalytically inactive (PPACK-treated) thrombin, like active thrombin, was able to inhibit the formation of TRAP + MNC (Fig. 3B).

In dose-response studies, a maximal response to thrombin was obtained with a concentration of

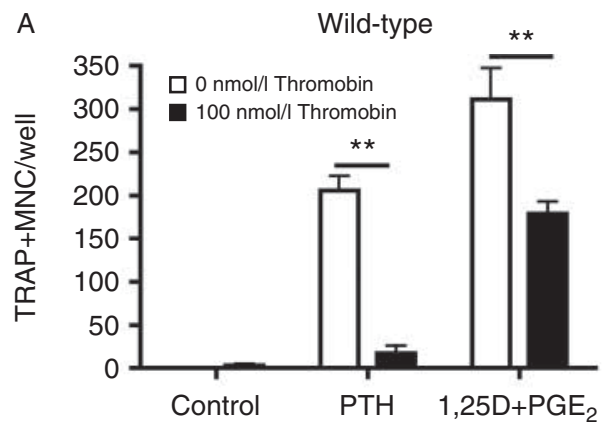

B

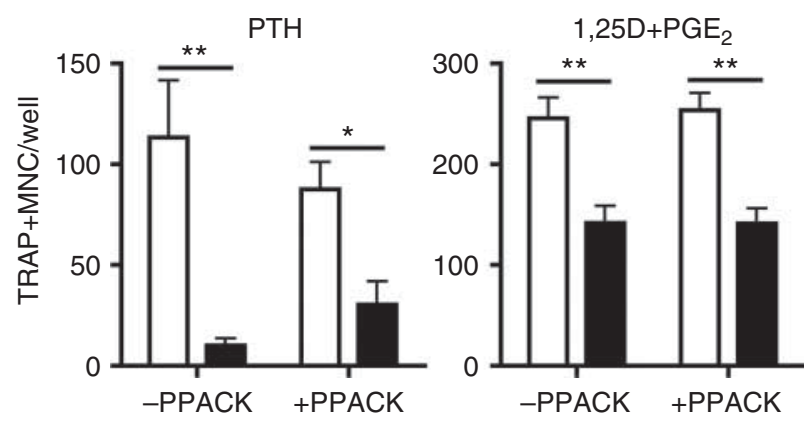

Figure 3

Effect of thrombin on osteoclast differentiation in mouse bone marrow

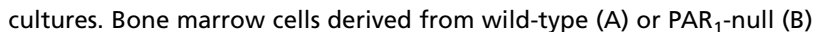
mice were cultured for 10 days then analysed for the presence of TRAP + MNC. Cells were cultured in the presence of PTH $(10 \mathrm{nmol} / \mathrm{l})$ or $1,25 \mathrm{D}(10 \mathrm{nmol} / \mathrm{l})$ and $\mathrm{PGE}_{2}(1 \mu \mathrm{mol} / \mathrm{l})$ or no hormone, in the absence or presence of thrombin $(100 \mathrm{nmol} / \mathrm{l})$. In (B), some cells were additionally treated with PPACK $(1 \mu \mathrm{mol} / \mathrm{l})$ or PPACK-inactivated thrombin $(100 \mathrm{nmol} / \mathrm{l})$. Results are expressed as mean \pm s.E.M. $(n=4)$; two-way ANOVA, Bonferroni's post-hoc test: ${ }^{*} P<0.05$ and $* * P<0.01$ for comparisons indicated by lines.

Published by Bioscientifica Ltd. 
$300 \mathrm{nmol} / \mathrm{l}$, but as this is close to the maximum concentration detected in clotted blood (Rand et al. 1996) and as the response to $100 \mathrm{nmol} / \mathrm{l}$ thrombin was close to maximal, the latter concentration was used for further experiments (Fig. 4A). The initial experiments were undertaken with thrombin purified from human plasma by the authors, but similar results were obtained with human plasma thrombin from a commercial source and with recombinant human thrombin (Fig. 4B). As with TRAP + MNC, there were fewer TRAP-positive cells with fewer than three nuclei in thrombin-treated than in control cultures (Fig. 4C and D).

\section{Are osteoclast precursors the direct target of thrombin's inhibitory activity?}

The fact that thrombin inhibited osteoclast differentiation in bone marrow cultures, although not influencing the RANKL:OPG ratio in bone marrow stromal cells, could perhaps be explained by osteoclast precursors being the direct target of thrombin's inhibitory activity. The effect of thrombin on osteoclast differentiation in spleen cells treated with RANKL and M-CSF was, therefore, investigated. In wild-type spleen cell cultures, thrombin significantly inhibited the formation of TRAP + MNCs and a similar effect was observed in $\mathrm{PAR}_{1}$-null spleen cell cultures (Fig. 5A). Catalytically inactive thrombin also inhibited the formation of TRAP + MNCs in both wild-type and $\mathrm{PAR}_{1}$-null cultures (Fig. 5A).

Osteoclastogenesis is a multistep process, which involves proliferation of osteoclast precursors, followed by early differentiation as mononuclear cells, then fusion to form multinucleated osteoclasts. Mouse spleen cells induced to differentiate into osteoclasts were treated with thrombin for different times within the culture period, to determine which stage is affected by the presence of thrombin. In these experiments, thrombin was present for the entire culture period (0-7 days), or throughout the proliferative phase ( $0-3$ days), differentiation phase (3-5 days) or fusion phase (5-7 days). When spleen cells were cultured with thrombin either for the first 3 days or between days 3 and 5 , the number of TRAP + MNCs formed was similar to that observed in cultures treated with thrombin for the entire culture

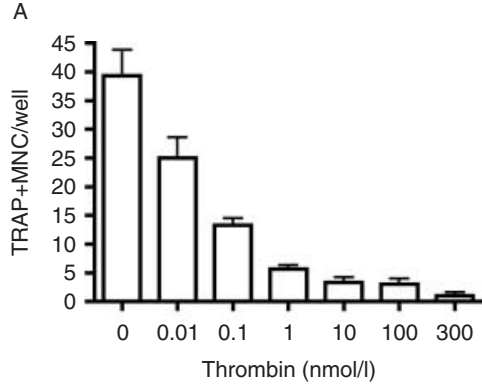

D

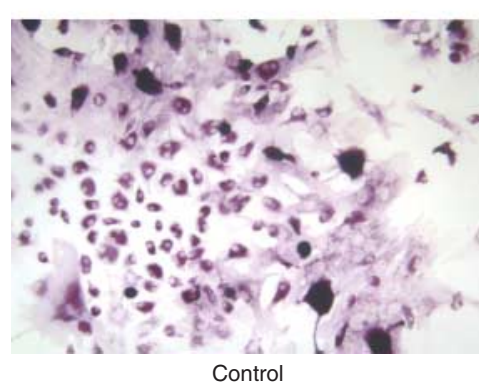

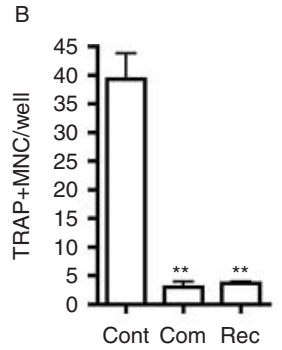
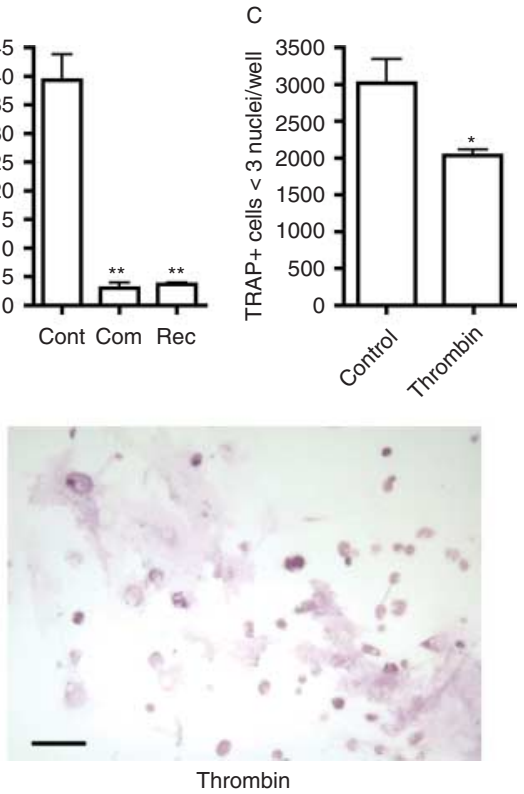

(A) Dose-response to thrombin. (B) Effect of thrombin from different sources. (C) Effect of thrombin on TRAP + cells with fewer than three nuclei. (D) Representative images of cultures. The magnification is the same in both images; bar $=100 \mu \mathrm{m}$. Data are presented as mean \pm s.E.M. $(n=3)$. Statistical analysis was performed using one-way ANOVA with Dunnett's multiple comparison test (B) and two-tailed Student's $t$-test (C): ${ }^{*} P<0.05$ and $* * P<0.01$ for comparisons between treatment and control values.

Published by Bioscientifica Ltd. http://jme.endocrinology-journals.org DOI: 10.1530/JME-12-0177
(C) 2013 Society for Endocrinology Printed in Great Britain 
A
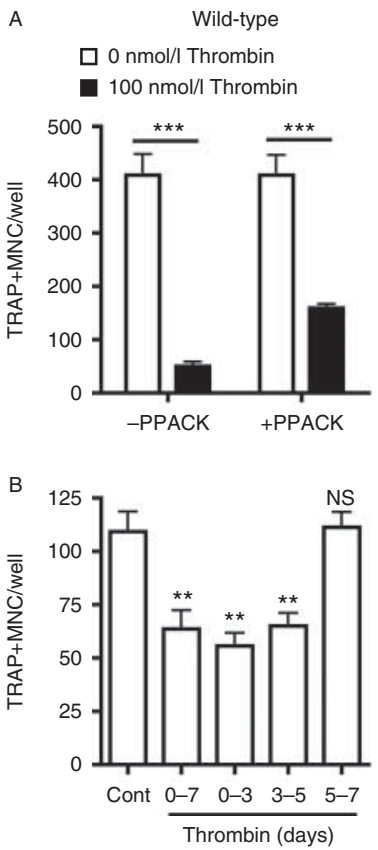
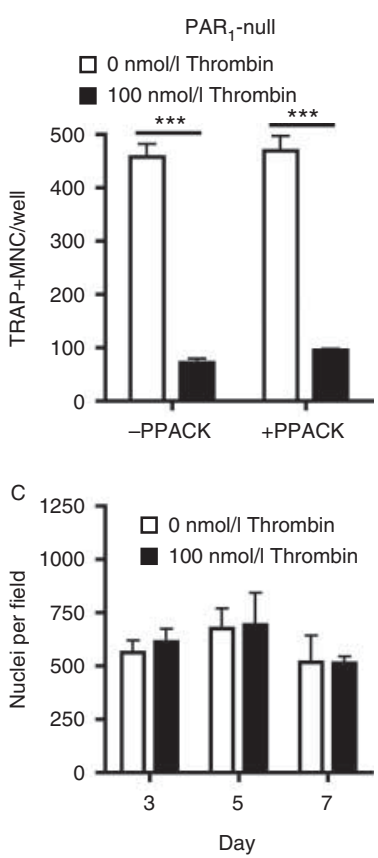

\section{Figure 5}

Effect of thrombin on osteoclast differentiation in mouse spleen cells. Spleen cells were cultured for 7 days (A and B) or 3,5 and 7 days (C) in the presence of RANKL and M-CSF, then analysed for the presence of TRAP + MNCs (A and B) or all adherent cells (C). (A) Spleen cells derived from either wild-type or $\mathrm{PAR}_{1}$ null mice were treated with or without thrombin $(100 \mathrm{nmol} / \mathrm{l})$, PPACK $(1 \mu \mathrm{mol} / \mathrm{l})$ or PPACK-inactivated thrombin $(100 \mathrm{nmol} / \mathrm{l})$ for 7 days. (B) Spleen cells from wild-type mice; thrombin $(100 \mathrm{nmol} / \mathrm{l})$ was excluded from the medium (control), or included for 7 days (0-7), for the first 3 days (0-3), between days 3 and 5 (3-5) or between days 5 and 7 (5-7). (C) Spleen cells from wild-type mice were treated with or without commercial thrombin $(100 \mathrm{nmol} / \mathrm{l})$; the total number of nuclei in adherent cells was counted. Results are expressed as mean \pm s.E.M. $(n=5$ in (A and B); $n=3$ in (C)). Statistical analysis was performed using two-way ANOVA with Bonferroni's post-hoc test (A and C) and one-way ANOVA with Dunnett's multiple comparison test $(\mathrm{B}): * * * P<0.001$ for comparisons indicated by lines in (A); NS, not significantly different, $* * P<0.01$ for comparisons between treatment and control values in (B).

period, i.e. significantly lower than in controls (Fig. 5B). However, the presence of thrombin between days 5 and 7 did not inhibit the formation of TRAP + MNCs (Fig. 5B). In another experiment, some control cultures were stopped at day 5 as well as at day 7 ; in this experiment, there were significantly more $(P<0.05$; $t$-test $) \mathrm{TRAP}+\mathrm{MNCs}$ at day 7 $(187 \pm 28)$ than at day $5(75 \pm 4)$, confirming that the majority of fusion occurred from days 5 to 7 . The total number of nuclei in adherent cells was counted in spleen cell cultures at days 3, 5 and 7; there was no significant difference between thrombin-treated and control cultures at any time point (Fig. 5C).

The ability of thrombin to inhibit differentiation of human osteoclasts was also investigated. Human PBMCs

were cultured on dentine slices in the presence of RANKL and M-CSF; the slices were then processed for scanning electron microscopy and the area of resorption pits was measured (Fig. 6). Treatment with thrombin (either active or inactive) for the full 21-day culture period caused a significant reduction in resorption area, and the pits that were present were smaller than in control cultures (Fig. 6C and D). In this culture system, resorption commences between days 14 and 21 and continues thereafter (Sivagurunathan et al. 2005). Some cultures were maintained for 16 days in the absence of thrombin and then in the presence of thrombin for the remainder of the culture period; in these cultures, the resorption area was not significantly different from that of control cultures (Fig. 6E).

\section{Thrombin's inhibition of osteoclast differentiation: investigation of structural requirements}

When we first observed that thrombin inhibited osteoclast differentiation independently of $\mathrm{PAR}_{1}$, it occurred to us that thrombin may simply be acting through degradation of the RANKL or M-CSF produced by osteoblastic cells in bone marrow cultures and added to the culture medium in cultures of spleen cells or PBMCs. The finding that PPACK-inactivated thrombin was equally capable of inhibiting osteoclast differentiation appeared to rule out this possibility, but we chose to verify this conclusion using a second approach. RANKL or M-CSF were incubated with thrombin under conditions mimicking the culture conditions, then investigated for proteolysis using SDS-PAGE, followed by western blotting (for RANKL) or silver staining (for M-CSF). Thrombin treatment had no effect on the size of the bands observed for either of these proteins (Fig. 7A).

Thrombin's structure includes, in addition to the active site, exosites that assist in interactions with substrates and inhibitors and determine the specificity of such interactions. The possible involvement of these exosites in mediating thrombin's effect on osteoclast precursors was therefore examined in cultures of mouse spleen cells treated with RANKL and M-CSF, using hirudin fragment 54-65 (10 $\mu \mathrm{mol} / \mathrm{l}$; an exosite I ligand), heparin $(100 \mu \mathrm{g} / \mathrm{ml}$; an exosite II ligand) and thrombomodulin ( $200 \mathrm{nmol} / \mathrm{l}$; binds exosites I and II). Neither the hirudin fragment nor heparin affected thrombin's ability to inhibit the formation of TRAP + MNCs (Fig. 7B). Thrombomodulin alone significantly inhibited the formation of osteoclasts, thus it was not possible to determine whether it influenced thrombin's inhibitory activity (Fig. 7B). 

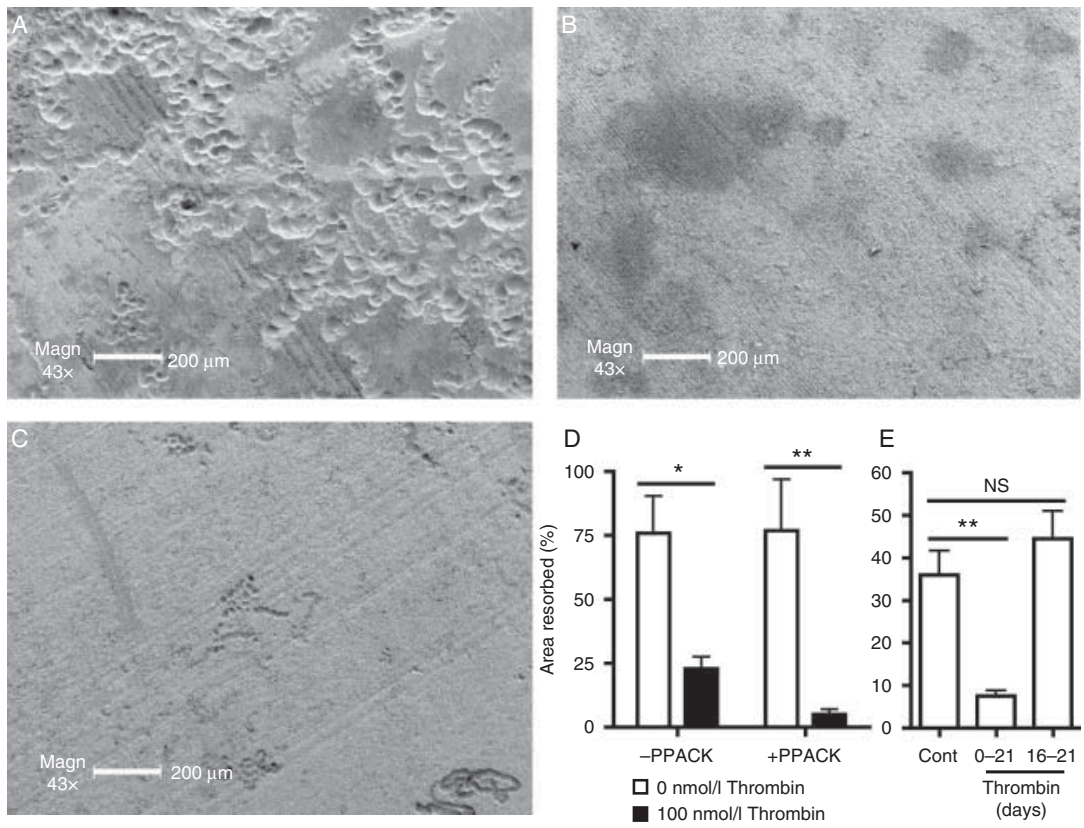

\section{Figure 6}

Effect of thrombin on osteoclast differentiation in human PBMCs. Human PBMCs were cultured for 21 days on dentine slices, which were then examined for resorption pits by scanning electron microscopy. Images of preparations cultured in medium containing RANKL and M-CSF (A), no additives (B) or thrombin (100 $\mathrm{nmol} / \mathrm{l})$, RANKL and M-CSF (C); bar $=200 \mu \mathrm{m}$. ( $D$ and $E$ ) Resorption area in preparations treated with M-CSF and RANKL in the presence of no further additives, thrombin $(100 \mathrm{nmol} / \mathrm{l})$, PPACK

\section{Effect of thrombin on expression of osteoclast genes}

The ability of thrombin to influence the expression of genes expressed by cells of the osteoclast lineage that are essential for osteoclast differentiation was investigated by qRT-PCR in spleen cell cultures treated with RANKL and M-CSF for 1, 3 or 5 days. Thrombin had no effect on mRNA expression of c-fms (the M-CSF receptor), c-fos or Oscar (data not shown), but in thrombin-treated cultures there was no detectable RANK expression at day 3 or 5 , whereas it was present in control cultures (Fig. 8).

\section{Discussion}

Thrombin has previously been shown to stimulate the release of osteoclastogenic factors such as IL6 and prostanoids by osteoblasts. This leads to our hypothesis that thrombin-induced secretion of IL6 and $\mathrm{PGE}_{2}$ gives rise to an increase in the ratio of RANKL:OPG in osteoblastic cells and thus increased osteoclast differentiation in mixed populations of cells of the osteoblast and osteoclast lineages, such as are found in bone marrow. Initial experiments
$(1 \mu \mathrm{mol} / \mathrm{l})$ or PPACK-inactivated thrombin $(100 \mathrm{nmol} / \mathrm{l})$. Thrombin was present for 21 days in (D), and from either days 0 to 21 or 16 to 21 in (E). Results are expressed as mean \pm s.E.M. $(n=3-5)$. Statistical analysis was performed using two-way ANOVA with Bonferroni's post-hoc test (D) and one-way ANOVA with Dunnett's multiple comparison test (E): NS, not significantly different, ${ }^{*} P<0.05$ and $* * P<0.01$ for comparisons indicated by lines.

confirmed that thrombin does indeed cause an increase in the ratio of RANKL:OPG in osteoblasts, but similar experiments with mouse bone marrow stromal cells demonstrated that thrombin does not influence the ratio in these less differentiated cells. Thus, when it was observed that, rather than inducing osteoclast differentiation in bone marrow cultures, as originally predicted, thrombininhibited osteoclast differentiation induced by PTH or 1, 25D and $\mathrm{PGE}_{2}$, it seemed likely that this effect may be mediated by a direct effect of thrombin on osteoclast precursors.

The possibility that thrombin exerts direct effects on osteoclast precursors, inhibiting their differentiation, was investigated using two different sources of osteoclast precursors (mouse spleen cells and human PBMCs), in the absence of cells of the osteoblast lineage. As thrombin reproducibly inhibited osteoclast differentiation induced by M-CSF and RANKL in these cells, it can be concluded that thrombin acts directly on osteoclast precursors to elicit this effect.

The period during which thrombin is able to inhibit osteoclast formation appears to be in the pre-fusion stages, because thrombin added to spleen cell cultures for

Published by Bioscientifica Ltd. 
A

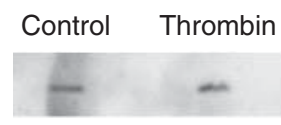

RANKL

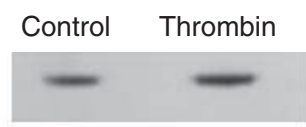

M-CSF
B

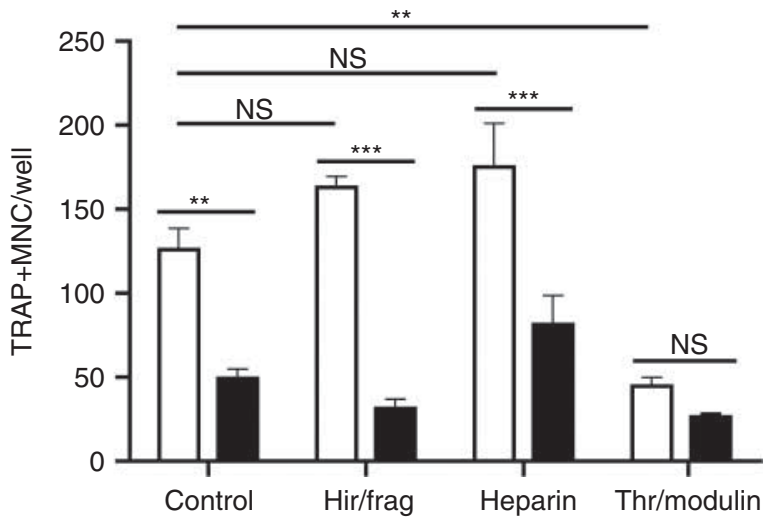

\section{Figure 7}

Structural requirements for thrombin inhibition of osteoclast differentiation. (A) RANKL $(30 \mathrm{ng} / \mathrm{ml})$ or M-CSF $(25 \mathrm{ng} / \mathrm{ml})$ were incubated in the absence or presence of thrombin at $37^{\circ} \mathrm{C}$ for $30 \mathrm{~min}$, then analysed by SDS-PAGE followed by western blotting (RANKL) or silver staining (M-CSF). (B) Spleen cells derived from $\mathrm{PAR}_{1}$ null mice were cultured for 7 days in the presence of RANKL and M-CSF, then analysed for the presence of TRAP+ MNCs. Some wells were treated with hirudin fragment 54-65 (Hir/frag; $10 \mu \mathrm{mol} / \mathrm{l})$, heparin $(100 \mu \mathrm{g} / \mathrm{ml})$ or thrombomodulin (Thr/modulin; $200 \mathrm{nmol} / \mathrm{l})$ in the presence or absence of thrombin $(100 \mathrm{nmol} / \mathrm{l})$ for the first 3 days of culture. Statistical analysis was performed using two-way ANOVA with Bonferroni's post-hoc test (for analysis of the effect of thrombin) and one-way ANOVA with Dunnett's multiple comparison test (for comparison between inhibitors and control). Results are expressed as mean \pm s.E.M. $(n=3-5)$. NS, not significantly different, $* * P<0.01$ and $* * * P<0.001$ for comparisons indicated by lines.

days $0-3$ or 3-5 significantly decreased osteoclast numbers, whereas thrombin present only for days $5-7$ had no effect. Thrombin did not influence the number of nuclei in adherent cells at any stage of culture, indicating that it has no effect on adhesion, proliferation or survival, and leading to the conclusion that thrombin exerts its effect by inhibiting pre-fusion differentiation. This conclusion is in accordance with the finding that thrombin completely suppressed expression of RANK mRNA, which would be expected to render the osteoclast precursors unresponsive to RANKL. Further evidence for the conclusion that thrombin has little or no inhibitory effect on fusion is that there were not only fewer TRAP + MNCs in thrombintreated bone marrow cultures but also fewer TRAP-positive cells with fewer than three nuclei; if thrombin's major effect was to inhibit fusion, it would be expected that it would instead cause accumulation of these cells. Thrombin was also unable to influence resorptive activity when added to mature PBMC-derived osteoclasts.

Further studies were undertaken in an attempt to identify various aspects of the mechanism of thrombin's inhibition of osteoclast differentiation. We asked the question whether $\mathrm{PAR}_{1}$, which mediates most of the well-characterised responses of cells to thrombin, is responsible for this effect on osteoclast precursors. Indeed, $\mathrm{PAR}_{1}$ is known to be expressed by PBMCs (Hoffman \& Church 1993, Colognato et al. 2003). Thrombin inhibited osteoclast differentiation in both bone marrow and spleen cell cultures isolated from $\mathrm{PAR}_{1}$-null mice, demonstrating that this receptor does not mediate thrombin's effect. $\mathrm{PAR}_{3}$ and $\mathrm{PAR}_{4}$ are also described as thrombin receptors; however, $\mathrm{PAR}_{3}$ appears to act solely as a cofactor for $\mathrm{PAR}_{4}$ (Nakanishi-Matsui et al. 2000, Mackie et al. 2008);
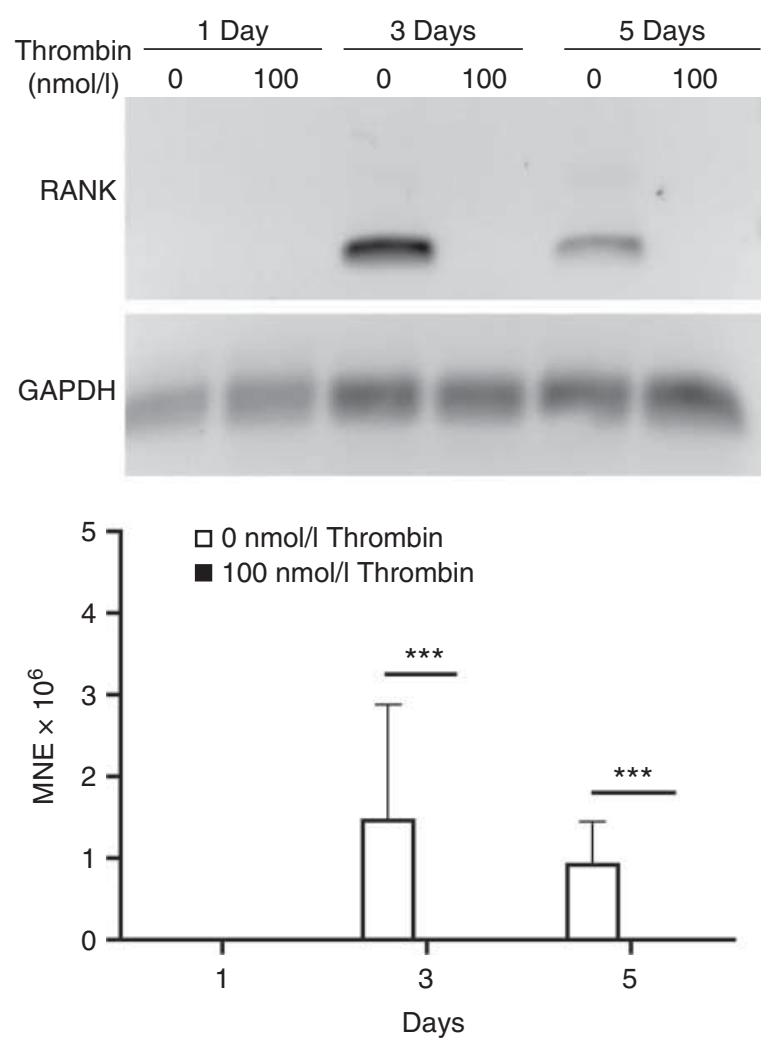

\section{Figure 8}

Effect of thrombin on expression of RANK in spleen cell cultures. Spleen cells were cultured for 1, 3 or 5 days in the presence of RANKL and M-CSF in the absence or presence of commercial thrombin $(100 \mathrm{nmol} / \mathrm{l})$, then RNA was extracted and analysed by qRT-PCR for expression of RANK. Upper panel: RANK and GAPDH reaction products following 70 cycles were run on agarose gels for visualisation. Lower panel: statistical analysis was performed using REST-384 Software. Results are expressed as mean \pm s.E.M. $(n=3) . * * * P<0.001$ for comparisons indicated by lines. 
although $\mathrm{PAR}_{3}$ is expressed by PBMCs, $\mathrm{PAR}_{4}$ is not (Colognato et al. 2003), thus ruling out these PARs as possible mediators of thrombin's effect. The fact that thrombin's proteolytic activity was not required for its effect on osteoclast differentiation provides further evidence that PARs do not mediate this response.

There is a substantial body of published evidence indicating the existence of at least two non-PAR receptors for thrombin, but these receptors have not been identified. We have demonstrated that thrombin inhibits apoptosis of osteoblasts and skeletal muscle myoblasts independently of any of the PARs (Chinni et al. 1999, Pagel et al. 2003). This effect requires thrombin's proteolytic activity, thus the receptor involved cannot be the same as that responsible for thrombin's inhibition of osteoclast differentiation. Proteolysis-independent responses of cells to thrombin have also previously been described. For example, proteolytically inactive thrombin induces chemotaxis of neutrophils and PBMCs and a nonproteolytic thrombin peptide induces cytokine release from PBMCs (Bar-Shavit et al. 1983, Bizios et al. 1986, Crago et al. 1995, Jenkins et al. 1995, Naldini et al. 2004). The receptor responsible for one or all of these effects may also be responsible for thrombin's inhibition of osteoclast differentiation. Thrombin's structure includes the RGD sequence that is used by many extracellular matrix proteins to bind to cell adhesion receptors including integrins. When osteoclasts isolated from neonatal rat long bones are plated on different substrata, prothrombin and thrombin selectively support adhesion of small osteoclasts in an RGD-dependent manner, whereas osteopontin and fibronectin support adhesion of larger, more active osteoclasts ( $\mathrm{Hu}$ et al. 2008). As noted above, thrombin does not appear to have affected cell adhesion in osteoclastogenic cultures in the current study.

The effects of molecules known to interact with wellcharacterised regions of thrombin outside its active site were investigated to obtain some additional information concerning the interaction of thrombin with osteoclast precursors. From these experiments it can be concluded that neither exosite I nor exosite II is required for thrombin's inhibition of osteoclast differentiation, because thrombin's effect was not inhibited by either the hirudin fragment or heparin.

In the current study, thrombin's inhibition of osteoclast differentiation was reproducible across three different culture systems and two different species, indicating that this is likely to be an important effect of thrombin in vivo. Thrombin is present in coagulated blood immediately following bone injury. We have previously made a number of observations indicating that thrombin supports osteoblastic bone formation at sites of injury: thrombin stimulates proliferation of osteoblasts and bone marrow stromal cells (in a $\mathrm{PAR}_{1}$-dependent manner); thrombin inhibits apoptosis of osteoblasts and bone marrow stromal cells (in a $\mathrm{PAR}_{1}$-independent manner); and new bone formation is delayed in $\mathrm{PAR}_{1}$-null mice following bone injury (Abraham \& Mackie 1999, Pagel et al. 2003, Song et al. 2005a,b). The results presented here suggest that while thrombin is supporting rapid new bone formation through its effects on cells of the osteoblast lineage, it is simultaneously suppressing osteoclast differentiation, thus ensuring that the first new bone formed is not immediately removed and has a chance to restore structural integrity as soon as possible. The fact that thrombin was found to inhibit RANKL-induced osteoclast differentiation through direct effects on osteoclast precursors is noteworthy, because it indicates that thrombin is able to counteract the pro-osteoclastogenic effects of the inflammatory milieu of a recent fracture; many proinflammatory molecules known to be present in recently injured bone (such as IL6 and prostaglandins) stimulate osteoclast differentiation indirectly through induction of RANKL expression by osteoblastic or other cells (Dekel et al. 1981, Einhorn et al. 1995, Okada et al. 2000, Braun \& Zwerina 2011). Indeed, thrombin itself must contribute to the inflammatory nature of the fracture site through induction of osteoblastic expression of IL6 and $\mathrm{PGE}_{2}$, but here we demonstrate that thrombin also acts downstream from these factors through its direct inhibitory effect on osteoclast precursors and thus overrides its own apparent pro-osteoclastogenic effects on osteoblasts.

Thrombin and prothrombin have been identified in bone extracts using biochemical methods and in bone matrix using immunoelectron microscopy (Lecrone et al. 2000, van den Bos et al. 2008, Hu et al. 2008), although contradictory data have been published as to whether prothrombin mRNA is expressed in bone (Song et al. 2005a, Karlstrom et al. 2011); thus, it is possible that active thrombin is present in normal bone. Another possible source of thrombin in the bone environment is skeletal muscle. Prothrombin is expressed by skeletal muscle, and cholinergic stimulation of muscle in vitro results in generation of active thrombin (Citron et al. 1997, Glazner et al. 1997, Kim et al. 1998). These observations suggest that the periosteal surfaces of bone in contact with muscle may be exposed to thrombin, especially during exercise. Thrombin released by exercising muscle may contribute to the anabolic effects of exercise on bone not only through

Published by Bioscientifica Ltd. 
its effects on osteoblasts but also by suppressing osteoclast differentiation.

No clear information is available from in vivo studies concerning the role of thrombin in bone metabolism. Genetic elimination of prothrombin expression in mice causes a high rate of lethality at mid-gestation; the surviving animals are described as being born with no obvious abnormality but die soon after birth due to a bleeding disorder (Sun et al. 1998). Mice in which prothrombin expression is eliminated in adulthood die within 7 days of prothrombin depletion (Mullins et al. 2009). The skeletal phenotype has not been described for either of these strains of mice. Treatment with the anticoagulant heparin is associated with an increased incidence of fragility fractures in women (Mazziotti et al. 2010). In the current study, heparin failed to inhibit thrombin's effect on osteoclastogenesis, but in addition to its direct interaction with thrombin, heparin also inhibits thrombin generation by acting at multiple stages of the coagulation cascade. The effect of heparin on fracture incidence may, therefore, be due to the reduced availability of thrombin to inhibit osteoclast differentiation, but as heparin interacts with many molecules in the bone environment, there are other possible mechanisms for heparin's effect on fracture incidence.

It has been known for many years that thrombin exerts pro-anabolic effects on cells of the osteoblast lineage, but the results presented here demonstrate for the first time that thrombin also exerts anti-catabolic effects on cells of the osteoclast lineage. It can be concluded, therefore, that thrombin plays an overwhelmingly anabolic role in bone.

\section{Declaration of interest}

The authors declare that there is no conflict of interest that could be perceived as prejudicing the impartiality of the research reported.

\section{Funding}

This work was partially supported by the National Health and Medical Research Council of Australia (Programme grant number 284233).

\section{Author contribution statement}

All authors conceived and designed the experiments. S S, C N P, L H L and $\mathrm{LCW}$ performed the experiments. S S, CN P, L H L and E J M analysed the data. S S, C N P, R N P and E J M wrote the paper.

\section{Acknowledgements}

The authors would like to thank Dr S R Coughlin (University of California, San Francisco) for making the $\mathrm{PAR}_{1}$-null mice available and Ms Su Toulson for the care of the mice.

\section{References}

Abraham LA \& Mackie EJ 1999 Modulation of osteoblast-like cell behavior by activation of protease-activated receptor-1. Journal of Bone and Mineral Research 14 1320-1329. (doi:10.1359/jbmr.1999.14.8.1320)

Bar-Shavit R, Kahn A, Wilner GD \& Fenton JW II 1983 Monocyte chemotaxis: stimulation by specific exosite region in thrombin. Science 220 728-731. (doi:10.1126/science.6836310)

Bizios R, Lai L, Fenton JW II \& Malik AB 1986 Thrombin-induced chemotaxis and aggregation of neutrophils. Journal of Cellular Physiology 128 485-490. (doi:10.1002/jcp.1041280318)

van den Bos T, Speijer D, Bank RA, Bromme D \& Everts V 2008 Differences in matrix composition between calvaria and long bone in mice suggest differences in biomechanical properties and resorption: special emphasis on collagen. Bone 43 459-468. (doi:10.1016/j.bone.2008.05.009)

Braun T \& Zwerina J 2011 Positive regulators of osteoclastogenesis and bone resorption in rheumatoid arthritis. Arthritis Research \& Therapy $\mathbf{1 3}$ 235. (doi:10.1186/ar3380)

Chinni C, de Niese MR, Tew DJ, Jenkins AL, Bottomley SP \& Mackie EJ 1999 Thrombin, a survival factor for cultured myoblasts. Journal of Biological Chemistry 274 9169-9174. (doi:10.1074/jbc.274.14.9169)

Citron BA, Smirnova IV, Zoubine MN \& Festoff BW 1997 Quantitative PCR analysis reveals novel expression of prothrombin mRNA and regulation of its levels in developing mouse muscle. Thrombosis Research $\mathbf{8 7}$ 303-313. (doi:10.1016/S0049-3848(97)00132-1)

Colognato R, Slupsky JR, Jendrach M, Burysek L, Syrovets T \& Simmet T 2003 Differential expression and regulation of protease-activated receptors in human peripheral monocytes and monocyte-derived antigen-presenting cells. Blood 102 2645-2652. (doi:10.1182/blood2002-08-2497)

Connolly AJ, Ishihara H, Kahn ML, Farese RV Jr \& Coughlin SR 1996 Role of the thrombin receptor in development and evidence for a second receptor. Nature 381 516-519. (doi:10.1038/381516a0)

Crago AM, Wu HF, Hoffman M \& Church FC 1995 Monocyte chemoattractant activity of Ser195 $\rightarrow$ Ala active site mutant recombinant $\alpha$-thrombin. Experimental Cell Research 219 650-656. (doi:10.1006/excr. 1995.1275)

Dekel S, Lenthall G \& Francis MJ 1981 Release of prostaglandins from bone and muscle after tibial fracture. An experimental study in rabbits. Journal of Bone and Joint Surgery. British Volume 63 185-189.

Einhorn TA, Majeska RJ, Rush EB, Levine PM \& Horowitz MC 1995 The expression of cytokine activity by fracture callus. Journal of Bone and Mineral Research 10 1272-1281. (doi:10.1002/jbmr.5650100818)

Feyen JH, van der Wilt G, Moonen P, Di Bon A \& Nijweide PJ 1984 Stimulation of arachidonic acid metabolism in primary cultures of osteoblast-like cells by hormones and drugs. Prostaglandins 28 769-781. (doi:10.1016/0090-6980(84)90034-0)

Glazner GW, Yadav K, Fitzgerald S, Coven E, Brenneman DE \& Nelson PG 1997 Cholinergic stimulation increases thrombin activity and gene expression in cultured mouse muscle. Brain Research. Developmental Brain Research 99 148-154. (doi:10.1016/S0165-3806(96)00213-1)

Hoffman M \& Church FC 1993 Response of blood leukocytes to thrombin receptor peptides. Journal of Leukocyte Biology 54 145-151.

Howard CV \& Reed MG 1998. In Unbiased Stereology: Three Dimensional Measurement in Microscopy. New York: Springer.

$\mathrm{Hu}$ Y, Ek-Rylander B, Karlstrom E, Wendel M \& Andersson G 2008 Osteoclast size heterogeneity in rat long bones is associated with differences in adhesive ligand specificity. Experimental Cell Research $\mathbf{3 1 4}$ 638-650. (doi:10.1016/j.yexcr.2007.11.008)

Jenkins AL, Howells GL, Scott E, Le Bonniec BF, Curtis MA \& Stone SR 1995 The response to thrombin of human neutrophils: evidence for two novel receptors. Journal of Cell Science 108 (Pt 9) 3059-3066.

John V, Hock JM, Short LL, Glasebrook AL \& Galvin RJ 1996 A role for CD8 + T lymphocytes in osteoclast differentiation in vitro. Endocrinology 137 2457-2463. (doi:10.1210/en.137.6.2457)

Published by Bioscientifica Ltd. 
Johnson DJ, Adams TE, Li W \& Huntington JA 2005 Crystal structure of wild-type human thrombin in the $\mathrm{Na}+$-free state. Biochemical Journal 392 21-28. (doi:10.1042/BJ20051217)

Karlstrom E, Norgard M, Hultenby K, Somogyi-Ganss E, Sugars R, Andersson G \& Wendel M 2011 Localization and expression of prothrombin in rodent osteoclasts and long bones. Calcified Tissue International 88 179-188. (doi:10.1007/s00223-010-9443-3)

Kim S, Buonanno A \& Nelson PG 1998 Regulation of prothrombin, thrombin receptor, and protease nexin-1 expression during development and after denervation in muscle. Journal of Neuroscience Research 53 304-311. (doi:10.1002/(SICI)1097-4547(19980801)53:3 <304::AIDJNR4 > 3.0.CO;2-E)

Kozawa O, Tokuda H, Kaida T, Matsuno H \& Uematsu T 1997 Thrombin regulates interleukin-6 synthesis through phosphatidylcholine hydrolysis by phospholipase D in osteoblasts. Archives of Biochemistry and Biophysics 345 10-15. (doi:10.1006/abbi.1997.0232)

Lecrone V, Li W, Devoll RE, Logothetis C \& Farach-Carson MC 2000 Calcium signals in prostate cancer cells: specific activation by bonematrix proteins. Cell Calcium 27 35-42. (doi:10.1054/ceca.1999.0083)

Li X, Okada Y, Pilbeam CC, Lorenzo JA, Kennedy CR, Breyer RM \& Raisz LG 2000 Knockout of the murine prostaglandin EP2 receptor impairs osteoclastogenesis in vitro. Endocrinology 141 2054-2061. (doi:10.1210/ en.141.6.2054)

Mackie EJ, Loh LH, Sivagurunathan S, Uaesoontrachoon K, Yoo HJ, Wong D, Georgy SR \& Pagel CN 2008 Protease-activated receptors in the musculoskeletal system. International Journal of Biochemistry \& Cell Biology 40 1169-1184. (doi:10.1016/j.biocel.2007.12.003)

Mazziotti G, Canalis E \& Giustina A 2010 Drug-induced osteoporosis: mechanisms and clinical implications. American Journal of Medicine $\mathbf{1 2 3}$ 877-884. (doi:10.1016/j.amjmed.2010.02.028)

Minkin C 1982 Bone acid phosphatase: tartrate-resistant acid phosphatase as a marker of osteoclast function. Calcified Tissue International $\mathbf{3 4}$ 285-290. (doi:10.1007/BF02411252)

Morrissey JH 1981 Silver stain for proteins in polyacrylamide gels: a modified procedure with enhanced uniform sensitivity. Analytical Biochemistry 117 307-310. (doi:10.1016/0003-2697(81)90783-1)

Muller PY, Janovjak H, Miserez AR \& Dobbie Z 2002 Processing of gene expression data generated by quantitative real-time RT-PCR. BioTechniques 32 1372-1374, 1376, 1378, 1379.

Mullins ES, Kombrinck KW, Talmage KE, Shaw MA, Witte DP, Ullman JM, Degen SJ, Sun W, Flick MJ \& Degen JL 2009 Genetic elimination of prothrombin in adult mice is not compatible with survival and results in spontaneous hemorrhagic events in both heart and brain. Blood $\mathbf{1 1 3}$ 696-704. (doi:10.1182/blood-2008-07-169003)

Nakanishi-Matsui M, Zheng YW, Sulciner DJ, Weiss EJ, Ludeman MJ \& Coughlin SR 2000 PAR3 is a cofactor for PAR4 activation by thrombin. Nature 404 609-613. (doi:10.1038/35007085)

Naldini A, Carraro F, Baldari CT, Paccani SR, Bernini C, Keherly MJ \& Carney DH 2004 The thrombin peptide, TP508, enhances cytokine release and activates signaling events. Peptides 25 1917-1926. (doi:10.1016/j.peptides.2004.05.017)

Okada Y, Lorenzo JA, Freeman AM, Tomita M, Morham SG, Raisz LG \& Pilbeam CC 2000 Prostaglandin G/H synthase-2 is required for maximal formation of osteoclast-like cells in culture. Journal of Clinical Investigation 105 823-832. (doi:10.1172/JCI8195)

Pagel CN, de Niese MR, Abraham LA, Chinni C, Song SJ, Pike RN \& Mackie EJ 2003 Inhibition of osteoblast apoptosis by thrombin. Bone 33 733-743. (doi:10.1016/S8756-3282(03)00209-6)

Pagel CN, Song SJ, Loh LH, Tudor EM, Murray-Rust TA, Pike RN \& Mackie EJ 2009 Thrombin-stimulated growth factor and cytokine expression in osteoblasts is mediated by protease-activated receptor- 1 and prostanoids. Bone 44 813-821. (doi:10.1016/j.bone.2008.12.031)

Pfaffl MW, Horgan GW \& Dempfle L 2002 Relative expression software tool (REST) for group-wise comparison and statistical analysis of relative expression results in real-time PCR. Nucleic Acids Research $\mathbf{3 0}$ e36. (doi:10.1093/nar/30.9.e36)

Rand MD, Lock JB, van't Veer C, Gaffney DP \& Mann KG 1996 Blood clotting in minimally altered whole blood. Blood 88 3432-3445.

Ross FP 2008 Osteoclast biology and bone resorption. In Primer on the Metabolic Bone Diseases and Disorders of Mineral Metabolism, 7th edn, pp 16-22. Ed CJ Rosen.. Washington, D.C.: American Society for Bone and Mineral Research.

Sivagurunathan S, Muir MM, Brennan TC, Seale JP \& Mason RS 2005 Influence of glucocorticoids on human osteoclast generation and activity. Journal of Bone and Mineral Research 20 390-398. (doi:10.1359/ JBMR.041233)

Smith RD, Brown B, Ikonomi P \& Schechter AN 2003 Exogenous reference RNA for normalization of real-time quantitative PCR. BioTechniques $\mathbf{3 4}$ 88-91.

Smith R, Ransjo M, Tatarczuch L, Song SJ, Pagel C, Morrison JR, Pike RN \& Mackie EJ 2004 Activation of protease-activated receptor-2 leads to inhibition of osteoclast differentiation. Journal of Bone and Mineral Research 19 507-516. (doi:10.1359/JBMR.0301248)

Song SJ, Pagel CN, Campbell TM, Pike RN \& Mackie EJ 2005a The role of protease-activated receptor-1 in bone healing. American Journal of Pathology 166 857-868. (doi:10.1016/S0002-9440(10) 62306-1)

Song SJ, Pagel CN, Pike RN \& Mackie EJ 2005b Studies on the receptors mediating responses of osteoblasts to thrombin. International Journal of Biochemistry \& Cell Biology 37 206-213. (doi:10.1016/j.biocel. 2004.04.026)

Stone SR \& Hofsteenge J 1986 Kinetics of the inhibition of thrombin by hirudin. Biochemistry 25 4622-4628. (doi:10.1021/bi00364a025)

Sun WY, Witte DP, Degen JL, Colbert MC, Burkart MC, Holmback K, Xiao Q, Bugge TH \& Degen SJ 1998 Prothrombin deficiency results in embryonic and neonatal lethality in mice. PNAS 95 7597-7602. (doi:10.1073/pnas. 95.13.7597)

Tatakis DN, Dolce C \& Dziak R 1989 Thrombin's effects on osteoblastic cells. I. Cytosolic calcium and phosphoinositides. Biochemical and Biophysical Research Communications 164 119-127. (doi:10.1016/0006291X(89)91691-4)

Tsubakihara M, Williams NK, Keogh A \& dos Remedios CG 2004 Comparison of gene expression between left atria and left ventricles from non-diseased humans. Proteomics 4 261-270. (doi:10.1002/pmic. 200300539)

Received in final form 5 February 2013

Accepted 18 February 2013

Accepted Preprint published online 18 February 2013 http://jme.endocrinology-journals.org DOI: 10.1530/JME-12-0177
() 2013 Society for Endocrinology Printed in Great Britain
Published by Bioscientifica Ltd 